\title{
Application of Poskestren as Health Promotion Strategy for Improving Clean and Healthy Behavior of Pesantren in East Java Province
}

\author{
Maygi Restu Yang Esa ${ }^{1}$, Muhammad Baharuddin Wisudawan Putra² ${ }^{2}$ Diyah Werdiningtyas, S.Gz \\ ${ }^{1}$ Undergraduate Student in Department Health Policy and Administration, Faculty of Public Health, Universitas \\ Airlangga, Surabaya, Indonesia, ${ }^{2}$ Undergraduate student in Department Health Promotion and Behavior, Faculty \\ of Public Health, Universitas Airlangga, Surabaya, Indonesia, ${ }^{3}$ Government employees in Sub Sector of Health \\ Promotion and Community Empowerment, Field of Public Health, Health Department of East Java Province, \\ Indonesia
}

\begin{abstract}
Islamic boarding schools (Pesantren) are Islamic educational institutions in Indonesia. The Ministry of Health of the Republic of Indonesia has launched a concept to encourage people to care about their health, namely the Clean and Healthy Behavior (PHBS). Islamic boarding schools also have health problems so they need attention in efforts to improve public health. The health effort undertaken at the Pesantren is Poskestren (Pesantren Health Care). Based on the Health Department Data of East Java Provincial (2019), there are 3,965 islamic boarding schools with 1,284 Poskestren in East Java province. Poskestren can be a solution in solving health problems in Pesantren. Therefore the Poskestren must be arranged properly. In health promotion there are health promotion strategies which consist of advocacy, community development, community empowerment and partnerships. This health promotion strategy can be a reference in the implementation of the Poskestren in Pesantren.
\end{abstract}

Keywords: Pesantren, Poskestren, PHBS, Health Promotion Strategy.

\section{Introduction}

Islamic boarding schools (Pesantren) are Islamic educational institutions in Indonesia. Pesatren can be said as one of the centers of gathering people who live together and carry out activities together so that it can be said to be an environment that is at risk of disease transmission. The highest diseases that can occur in pesantren include scabies, ARI, and gastritis. ${ }^{(1)}$ This can occur due to personal hygiene and poor environmental sanitation.

The Government of Indonesia through the Ministry of Health has launched ten indicators of clean and healthy behavior (PHBS). PHBS covers five settings, one of which is PHBS in schools/educational institutions. Pesantren as one type of educational institution needs special attention in the implementation of PHBS as an effort to improve the health status of residents in their environment.
Community empowerment is one of the health promotion strategies. Poskestren is a manifestation of community-based health efforts (UKBM) carried out in Pesantren. Poskestren prioritizes promotive and preventive services without neglecting the curative and rehabilitative aspects with the guidance of the Primary health care (Puskesmas).

Based on the Health Department Data of East Java Province (2019), there are 3,965 boarding schools with 1,284 Poskestren in East Java province. The Governor of East Java Province launched the East Java Santri Healthy and Blessing Program (SAJADAH) which is an effort to assist the Pesantren. The aim is to increase the level of independence of the Poskestren and PHBS in the pesantren environment. This assistance involved various sectors ranging from the pesantren community, the health office, the puskesmas and other partnerships.

Based on the description above, the researchers conducted a study related to the effectiveness of the 
Poskestren assistance program in increasing PHBS in the Pesantren of East Java Province.

\section{Method}

This research uses quantitative research method with a secondary data analysis approach. This study uses data sourced from Health Department of East Java Provinceand also the policy for the implementation of the Pesantren assistance program. Data processing in this study used the test of two non-parametric paired samples with the Wilcoxon test. Secondary data used ordinal scale by looking at the PHBS classification data before and after getting the Pesantren assistance program.

\section{Result}

Overview of the Achievement of the Poskestren Assistance Program (SAJADAH) in East Java Province: According to Health Department Data of East Java Province (2019), East Java Province has 3,965 Pesantren with 1,284 Poskestren. This shows that there are $32.38 \%$ of pesantren that have Poskestren. The following is a comparison chart of the number of pesantren and the number of Poskestren in the District/ City of East Java Province:

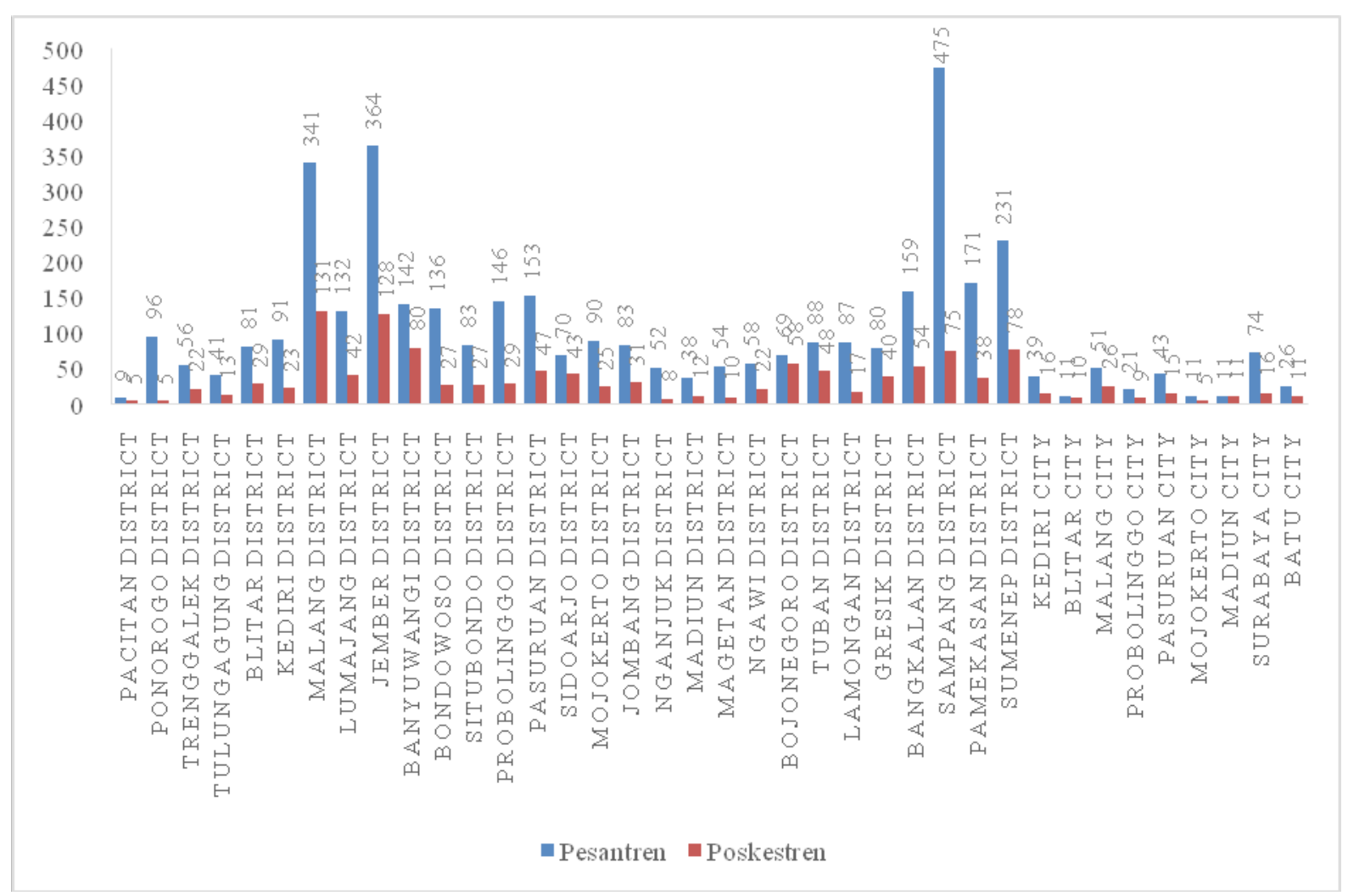

Figure 1. Number of Pesantren and Poskestren in District/City in East Java Province in 2019

Figure 1 shows that not all pesantren have Poskestren. This shows that health efforts in Pesantren in each region have not been running optimally. For example in Sampang District which has 475 Pesantren but only has 75 Poskestren (15.79\% of the total number of Pesantren).

PHBS scores were collected to find out the Poskestren classification. There are four classifications. The first classification is the Poskestren which has a value of one to five. The second classification is the Poskestren which has a value of six to ten. The third classification is the Poskestren which has values of eleven to fifteen. And the fourth classification has a value of sixteen to eighteen. Following are the success rates in (\%) of the Poskestren assistance program for improving the classification of PHBS in East Java Province in 2019: 


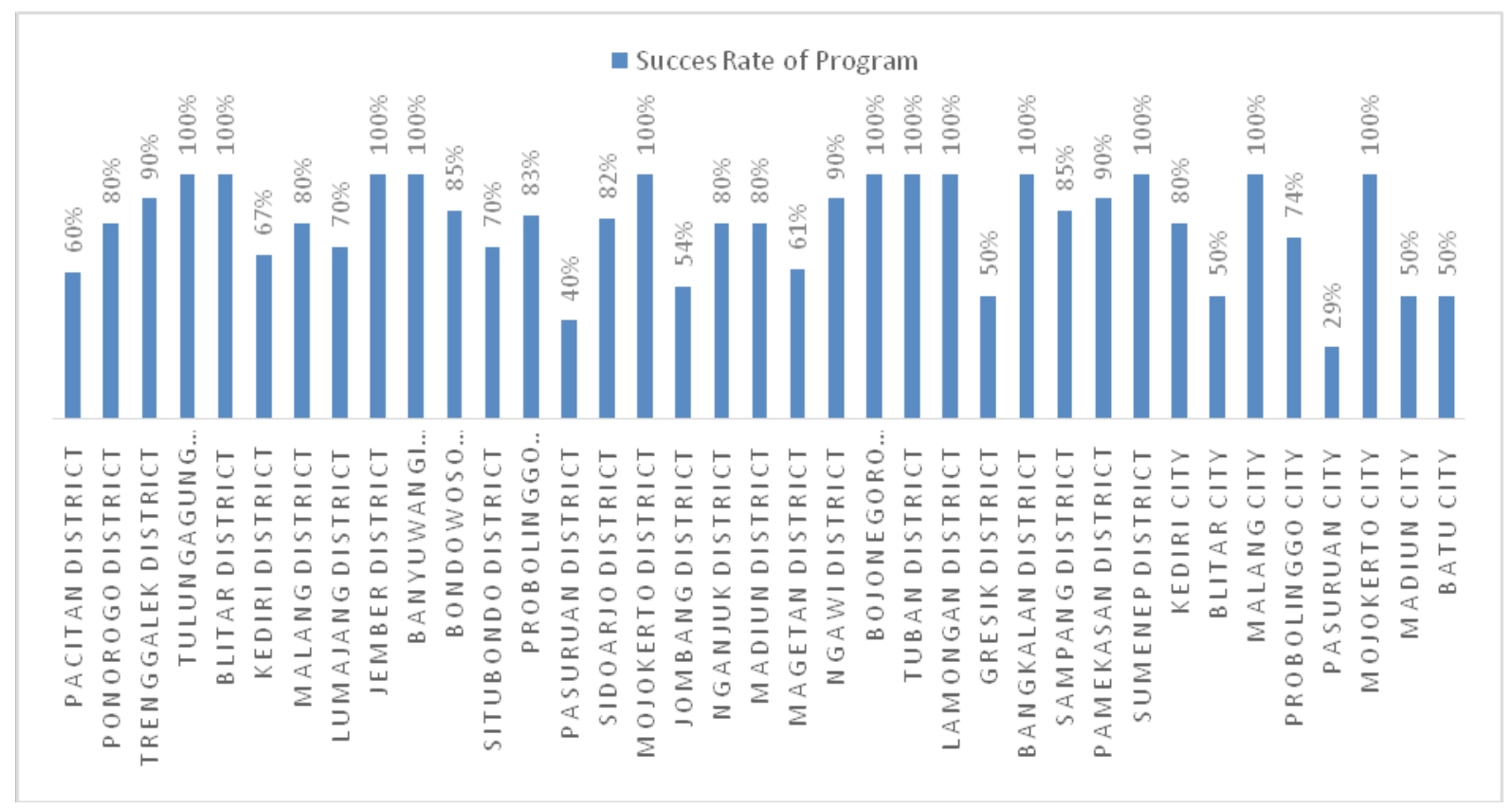

Figure 2. The Success Rate of the Poskestren Assistance Program Against PHBS in East Java Province in 2019

Figure 2 shows that there are 12 districts or cities that have increased PHBS by $100 \%$ with the Poskestren Assistance Program. There are only two districts or cities that have not reached a success rate of $50 \%$. The processed data shows that the data are not normally distributed (sig $0.0000<\alpha$ 0.05) so that the difference test for two Non Parametric Paired samples (Wilcoxon Test) is used. The Wilcoxon test results are sig 0,000 $<<\alpha 0.05$. It can be concluded that there are differences in Clean and Healthy Behavior (PHBS) between before the Poskestren Assistance Program and after the Poskestren Assistance Program. This shows that the assistance program for Poskestren was effective and succeeded in increasing PHBS in Pesantren.

\section{Discussion}

Poskestren as a Health Promotion Strategy in Pesantren: There is a relationship between the role of the poskestren and the Personal Hygiene behavior of adolescent santri in Al-Ghazaalie Islamic Boarding School Kranjingan, Sumbersari District, Jember District. (3). But there are also many other factors that influence this behavior.

Another study said that the health status of santri in a Pesantren that has a Poskestren is in a fairly good category consisting of three health sub-variables namely physical health in the good category $(100 \%)$, mental health in the pretty good category $(63 \%)$, and health the social category is quite good with a percentage of $43.8 \%{ }^{(10)}$ Therefore, every Pesantren needs to establish a Poskestren because if the Poskestren is run well, the health of the santri will improve, especially at the level of implementation of the Clean and Healthy Behavior (PHBS) of the santri.

Poskestren is present as one of the health promotion strategies in Pesantren. However, the existence of the Poskestren cannot guarantee that PHBS in the pesantren is good. A strategy is needed to run the Poskestren. The strategy in question is a health promotion strategy.

Health promotion strategies are based on the complexity of the nature of people's behavior. Based on the Decree of the Minister of Health No. 1114/MENKES/ SK/VII/2005 concerning Guidelines for Implementing Health Promotion in the Regions, health promotion is an effort to increase the community's capacity through learning from, by, for and with the comunity, so that they can help themselves, and develop communitybased activities, in accordance with local socio-culture and supported by health-oriented public policies.

To achieve the above objectives, the health promotion strategy implemented at the Poskestren contains four aspects. 
1. Advocacy: Advocacy is an approach and motivation towards certain parties which is calculated to be able to support the successful development of PHBS both in material and non material aspects. The parties involved are both formal and informal community leaders who generally act as resource persons (opinion leaders), or policy makers (norms) or funders. Other certain parties can also be in the form of society or mass media that can create a conducive atmosphere, public opinion and encouragement of the creation of community PHBS.

The factors influencing the success of the poskestren were knowledge, participation, motivation \& support, leadership, community potential, cooperation, and policy. ${ }^{(7)}$ While the failure factors in the Poskestren program were weak community participation and the emergence of a dependency towards the Ministry of Health assistance and District Health Office. This shows that Poskestren's internal commitment and external support for Poskestren affect the success of the Poskestren itself.

Policy is an example of the commitment of policy makers in an issue. Some regulations have been established by the government in the procurement of Poskestren as an effort to improve the degree of public health, especially in the pesantren environment.

\section{Supporting regulations and policies include:}

1. Regulation of the Minister of Health of the Republic of Indonesia Number 1 of 2013 concerning Guidelines for Organizing and Developing Poskestren which are guidelines for implementing Poskestren.

2. Joint Decree of the Minister of Health, Minister of Religion, and Minister of Home Affairs Number 1067/Menkes/SKB/VIII/2002, Number 385 of 2002, and Number 37 of 2002 concerning Improvement of the Health of Pesantren and Other Religious Institutions

3. Joint Decree of the Minister of National Education, Minister of Health, Minister of Religion, and Minister of Home Affairs Number 1/U/SKB/2003, Number 1067/Menkes/SKB/ $\mathrm{VII} / 2003$, Number MA/230A/2003, and Number 26 of 2003 about the Development and Development of School Health Enterprises.

4. Minister of Health Regulation No. 2269/
Menkes/Per/XI/2011 concerning Guidelines for the Development of Clean and Healthy Behavior (State Gazette of the Republic of Indonesia Number 755, 2011) which states that Pesantren are one of the targets of PHBS in educational institutions.

5. The program issued by the Governor of East Java in the form of SAJADAH which is an effort to assist Poskestren in East Java Pesantren.

2. Social Support: Community development is an effort to create a social environment that encourages individuals in community members to want to do the behavior that is introduced. Individual community members will be more motivated to engage in introduced behavior if community leaders or influential people in the environment approve or support the introduced behavior.

To achieve the objectives of fostering and enhancing the functions and performance of the Poskestren, the Puskesmas carries out several activities as the person responsible for the Poskestren in its area. The puskesmas started the formation of the Poskestren by coordinating with the leaders or managers of the Pesantren to approach it. This approach aims to prepare members of the pesantren so that they are willing to support the implementation of the Poskestren. Furthermore, the Self-Inspection Survey (SMD) was conducted involving members of the Pesantren. Puskesmas staff, and related stakeholders. The purpose of SMD is to recognize and identify health problems in the pesantren environment so that they can be considered in what interventions to take. The Puskesmas will also provide guidance and monitoring to help manage the Poskestren on a regular basis.

Improving services at the Poskestren must be based on the health needs of the pesantren community. Therefore there needs to be support for the availability and skills of the Poskestren resources. The Puskesmas assisted with the Pesantren apparatus will also form a Poskestren cadre called SantriHusada. SantriHusada together with the manager of the Poskestren who will later become the spearhead in moving the pesantren community to care about health. This will be the embryo of empowering the Pesantren community by developing and empowering the potential or resources of the Pesantren itself. 
Based on the Wilcoxon test it was stated that there were differences in PHBS between before and after the Poskestren assistance program (SAJADAH). This is consistent with a research that there is a significant relationship between self-sanitation and environmental sanitation socialization innovations through poskestren with santri attitudes towards sanitation. ${ }^{(11)}$ Socialization of self and environmental sanitation through poskestren is in the high category where socialization provides knowledge about self sanitation and the environment for students. In addition, socialization makes students more active in implementing cooperation in maintaining personal hygiene and the environment of the pesantren where they live and study.

3. Community Empowerment: In health promotion, community empowerment is a very important part. Empowerment is the process of providing information to health promotion targets continuously and continuously following the development of targets, and the process of helping targets to change from not knowing to knowing (knowledge aspects), from knowing to being willing (attitude aspects), and from wanting to be able (practice aspects) carry out the introduced behavior. Therefore success in empowerment is to make the target understand and realize that something (a health problem) is a problem for him and for the community so that it leads to the application of the introduced behavior.

Poskestren can bea facility forpesantren communities to obtain health information. Through the managers of the Poskestren and SantriHusada, information can be given continuously and continuously. This is because they live together directly so they understand the development of health problems in Pesantren. Health information from the Puskesmas and other health media is expected to be received by the Poskestren Manager and SantriHusada which can then be passed on to the Pesantren community. The puskesmas will also conduct regular training with the aim of implementing the Poskestren to provide information and intervention to the pesantren community appropriately.

4. Partnership: Partnerships must be promoted well in order to support the other three aspects of health promotion strategies. The partnership is based on the principles of equality, openness and mutual benefit. Partnerships with other individuals or groups will enable the implementation of the Poskestren to be even better.

Partners from Poskestren can support the implementation of Poskestren by providing resource assistance. The resources provided can be in the form of financial resources, materials, information, coaching and training. Stakeholders who can be an opportunity to become a Poskestren partner include Government Agencies or Institutions such as ministries of religion and health, Community Leaders, Community Organizations/NGOs, Business or private sector and Universities.

The government as the policy maker can play a role in formulating health-oriented policies to support health activities and programs in Pesantren. The government can also provide facilities in the form of cross-sector meeting and discussion. This can enable and assist Poskestren to establish broader partners.

Community leaders and organizations involved such as in the religious field can be a companion to the Poskestren. Human resource assistance can help in health improvement programs run by the Poskestren. This is because the Poskestren, Pesantren and Community Leaders/Community Organizations have emotional closeness to the Pesantren community. So that health programs or interventions carried out in solving health problems can be received with an appropriate approach.

The business or private sector has obligations related to social responsibility (CSR). Increasing the role of CSR can be an opportunity to improve the degree of public health. Businesses or the private sector can be involved in health promotion efforts such as involvement and assistance with the implementation of the Poskestren.

Higher education in Indonesia has Tri Darma Higher Education as its basic principle. One of the Tri Darma of Higher Education is "Community Service". The role of tertiary institutions is very clear to be able to make people equal in solving problems in their environment. The academic community can help the community through education and research to develop solutions or appropriate interventions for a problem. This can be an alternative for Poskestren to obtain information and human resources sources in intervening in health problems in Pesantren. 


\section{Conclusion}

The results of the Poskestren analysis as a health promotion strategy in the East Java Pesantren can be summarized as follows:

1. Poskestren Assistance Program (SAJADAH) is effective and has succeeded in increasing PHBS in Pesantren in East Java Province.

2. Advocacy becomes very important in health interventions by involving policy makers to make regulations and health-oriented references. The establishment of the Poskestren is based on health problems that often occur in Pesantren boarding schools.

3. Community Development becomes important to provide facilities to the Poskestren in its implementation. Starting from the preparation, planning, organizing and control stages.

4. Poskestren becomes a place for Pesantren community to manage their potential to improve the health status of Pesantren community. Therefore, Community Empowerment through Poskestren must be fostered and developed continuously to promote health and reduce morbidity.

5. Partnerships are needed to optimize the implementation of the Poskestren itself.

\section{Recommendation:}

1. Promoting the Poskestren program based on the Health Promotion Strategy and the needs of the pesantren community in the Pesantren of East Java Province.

2. The government and the person responsible for the Poskestren should bridge the Poskestren with the Business World or Private partnership.

Conflict of Interest: The authors have no conflict of interest with the material presented in this paper

\section{Sources of Funding: Nill}

Ethical Clearance: NIll. My paper is an idea and policy analysis to solve population problems, without any treatment to the respondent/informant

\section{Reference}

1. Adriansyah AA. Keterkaitan Antara Sanitasi Pondok Pesantren Dengan Kejadian Penyakit Yang Dialami Santri Di Pondok Pesantren Sunan Drajat.
Mtphj [Internet]. 2018 Aug. 24 [cited 2020 Aug. 1];1(1):4-13. Available from: https://journal2. unusa.ac.id/index.php/MTPHJ/article/view/752.

2. Bahruddin E, Hamdi AS. Metode Penelitian Kuantitatif Aplikasi Dalam $\mathrm{P}$ endidikan. Deepublish; 2015.

3. Fauzi Ahmad. Hubungan Peran Pos Kesehatan Pesantren (Poskestren) Dengan Perilaku Personal Hygiene Remaja Santri Pondok Pesantren DarulHikmah Al-Ghazaalie Kranjingan Kecamatan Sumbersari Kabupaten Jember [Skripsi]. Jember: Fakultas Kesehatan Universitas Muhammadiyah Jember; 2016

4. Health Department of East Java Province.Number of Islamic Boarding Schools, Number of Santri Hisada, and the Level of Development of the East Java Province 2019.Surabaya: Health Department of East Java Province; 2019.

5. Health Department of East Java Province.Petunjuk Teknis PendampinganPoskestren.Surabaya: Health Department of East Java Province; 2019.

6. Kompri.Manajemen \& Kepemimpinan Pondok Pesantren.Prenada Media; 2018.

7. Kusnaati E, Prabandari YS. Pemberdayaan Masyarakat Pondok Pesantren Melalui Pos Kesehatan Pesantren Di Kabupaten Tulungagung [Theses]. Yogyakarta: Universitas Gajah Mada; 2013.

8. Ministry of Health of the Republic of Indonesia. Promosi Kesehatan di Daerah Bermasalah Kesehatan: Panduan bagi Petugas Kesehatan di Puskesmas. Jakarta: Ministry of Health of the Republic of Indonesia; 2011.

9. Ministry of Health of the Republic of Indonesia. Pedoman penyelenggaraan Dan Pembinaan Pos Kesehatan Pesantren. Jakarta: Ministry of Health of the Republic of Indonesia; 2013.

10. Shalihah Nur. Gambaran Status Kesehatan Santri Pada Pondok Yang Memiliki Pos Kesehatan Pesantren Di Pesantren Ruhul Islam Anak Bangsa Aceh Besar [Theses]. Banda Aceh; Universitas Syiah Kuala; 2014.

11. Wahyudin U, Arifin HS.Sosialisasi Sanitasi Diri dan Lingkungan di Pesantren Salafi Melalui Pos Kesehatan Pesantren (Poskestren) Dalam Membentuk Sikap Santri Terhadap Sanitasi. Jurnal Kajian Komunikasi. 2015;3(2):148-153

12. Waryana. Promosi Kesehatan, Penyuluhan, dan Pemberdayaan Masyarakat. Nuha Medika; 2016 